\title{
Quinone Oxidoreductase 2 Serum Level that affecting the Psychotic Disorders of Methamphetamine Abusers
}

\author{
Dany H. Ludong ${ }^{1}$, A. Jayalangkara Tanra ${ }^{2}$, Mochammad Hatta ${ }^{3}$, Sonny T. Lisal ${ }^{4}$, Ismail Fikri ${ }^{5}$, Reza \\ Nasution $^{6}$, Tri Supartini ${ }^{7}$ \\ ${ }^{1}$ Doctor of Rehabilitation Center of Baddoka National Narcotics Agency, Makassar, ${ }^{2}$ Professor of Departement \\ of Psychiatry, Faculty of Medicine, Hasanuddin Univercity, Indonesia, ${ }^{3}$ Professor of Department of Moleculer \\ Biology and Immunology, Faculty of Medicine, Hasanuddin University, ${ }^{4}$ Professor of Departement of Psychiatry, \\ Faculty of Medicine, Hasanuddin Univercity, ${ }^{5}$ Postgraduate School of Medicine Doctoral Study Program, \\ Hasanuddin University, ${ }^{6}$ Postgraduate School of Medicine Doctoral Study Program, Hasanuddin University, \\ ${ }^{7}$ Jaffray Bible College, Makassar, Indonesia
}

\begin{abstract}
Background: Some evidence suggests that genetic factors contribute to susceptibility to drug abuse such as methamphetamin and that dopamine-quinone produced by dopamine might be involved in the mechanism of symptoms associated with psychotic methamphetamine (MAP). Quinone detoxification is catalyzed by a group of proteins, namely quinone oxidoreductase (NQO). In this study we analyzed serum NQO2 levels by examining ELISA Sandwich in clients who used methamphetamine. Methods: This research is a Case-Control to determine the contribution of NQO2 to the emergence of psychotic disorders due to methamphetamine abuse. The case group is residents who consume methamphetamine with psychotic characteristics, while the control group is clients who consume methamphetamine without psychotic characteristics Results: The mean value of NQO2 gene protein in the Elisa Sandwich examination for the case group was lower than the value of the control group $(1,246<3,657)$. The $t$ test showed the value of sig $($ Equal variances not assumed) $=0,000$ that value is less than $0.05(<0.05)$, this shows the difference in the value of content protein NQO2 between the case group and the control group. Then the cut-off point of the Receiver Operating Characteristic (ROC) curve in this study is recommended statistically between 1,960 and 2,165 , meaning that if the expression value of protein content $>2.165$ then the potential for psychotic suffering is great, on the other hand if $<1.960$, the potential is small for suffering from psychotics. Conclusion: The protein content of the NQO2 gene in the Elisa Sandwich examination between the case and control groups is different, the case group is lower than the control. While the CURVE ROC (Receiver Operating Characteristic) Cut-Off value is recommended statistically between 1,960 and 2,165.
\end{abstract}

Keywords: Methamphetamine, Dopamine, NQO2 serum level, Methamphetamine Psychotic.

\section{Introduction}

Recently, methamphetamine abuse has become a major problem and developed into an international problem $^{\mathbf{2 0}}$. According to the United Nations Office on Drugs and Crime (UNODC), methamphetamine is a dangerous substances and the $2^{\text {nd }}$ ranks after hashish/ cannabis in the $1^{\text {st }}$ rank of the 20 types of substances that are often misused ${ }^{\mathbf{1 9}}$. The prevalence of narcotics abuse in the world from 2006 to 2013 has increased ${ }^{19}$. In the last five years, the trend of amphetamine type has declined by around $15 \%$ in various countries, while the use of ecstasy has been reported to be stable (12). However, there has been a drastic increase (158\%) in the last five years namely the consumption of methamphetamine ${ }^{14,19,20}$. Methamphetamine abusers can also cause psychotic symptoms similar to schizophrenia (Schizophrenia-like psychosis) but there are also methamphetamine abusers who do not experience psychotic symptoms ${ }^{24,25}$. As a reference from several previous studies that contributed to our research, there are two sources of reference that we can point out, namely: 
a. Functional polymorphisms of the NQO2 gene is associated with methamphetamine psychosis. (Ohgake, S. at all, ${ }^{14,17}$.

b. Cognitive impairment is related to oxidative stress and chemokine levels in first psychotic episodes. (Martinez-Cengotitabengoa $M$ at all, Schizophr Res 2012, 137:66-72).

\section{Material and Method}

\section{Study Design and Subject}

This research is a case-control to determine the effect of NQO2 gene on the onset of psychotic symptoms due to methamphetamine abuse ${ }^{\mathbf{1 , 2 2}}$. The Selection Criteria for clients who only consume methamphetamine with a diagnosis of Behavioral Mental Disorders due to the use of methamphetamine addictive substances with psychotic characteristics for the case group, while those who do not have psychotic characteristics as a control group and are currently undergoing inpatient rehabilitation programs at the BNN Baddoka Rehabilitation Center. Inclusion Criteria: Methamphetamine abusers, aged 20 - 50 years old, qualify as methamphetamine abuse. Exclusion Criteria: Clients suffering from Mental Disorders and Behavior due to addictive substances other than methamphetamine. There is a history of hereditary disorders in the Psychotic group, suffering from Severe Physical Disease and consumption of polysubstance during the past year ${ }^{9,13}$.

\section{Population of Research: a. Case group:} Methamphetamine users have Psychotic disorders, after being examined with the criteria of the Brief Psychiatric Rating Scale (BPRS) and the Diagnostic And Statistical Manual of Mental Disorder (DSM V).

b. Control group: Methamphetamine type who do not experience Psychotic disorders (examination instruments also with BPRS and DSM V).

\subsection{Statistical Analysis}

Analysis of the data in this study (Elisa's protein content) using statistical application assistance, IBM SPSS version 24. To see the difference between the two samples, namely the case group and the control group, an independent $t$ test was performed. Then to determine the cut-off point between psychotic and non-psychotic (Specificity and Sensitivity), by Receiver Operational Characteristics Curve (ROC) test and then performed AUC test (Area Under Curve) so that cut-off from data obtained in both groups.

\section{Results}

Table 1. Characteristic of subject based on age and gender

\begin{tabular}{|c|c|c|c|c|c|}
\hline \multicolumn{3}{|c|}{ Distribution of case subjects $(n=30)$} & \multicolumn{3}{|c|}{ Distribution of control subjects $(n=30)$} \\
\hline Ages & $\mathrm{n}$ & $\%$ & Ages & $\mathrm{n}$ & $\%$ \\
\hline $\begin{array}{l}20-35 \mathrm{yrs} \\
36-50 \mathrm{yrs}\end{array}$ & $\begin{array}{l}27 \\
3\end{array}$ & $\begin{array}{l}90 \\
10\end{array}$ & $\begin{array}{l}20-35 \mathrm{yrs} \\
36-50 \mathrm{yrs}\end{array}$ & $\begin{array}{l}27 \\
3\end{array}$ & $\begin{array}{l}90 \\
10\end{array}$ \\
\hline \multicolumn{3}{|l|}{ Gender } & \multicolumn{3}{|l|}{ Gender } \\
\hline $\begin{array}{l}\text { Men } \\
\text { Women }\end{array}$ & $\begin{array}{l}29 \\
1\end{array}$ & $\begin{array}{l}96,7 \\
3\end{array}$ & $\begin{array}{l}\text { Men } \\
\text { Women }\end{array}$ & $\begin{array}{l}30 \\
0\end{array}$ & $\begin{array}{l}100 \\
0\end{array}$ \\
\hline
\end{tabular}

Table 1 shows that the age of the subjects in the case group ranged from 20-35 years (90\%), most of the men were $29(96.7 \%)$, and the rest were women. 


\section{T-Test}

Independent $\mathrm{t}$ test is a test to see the difference between the two sample groups, namely cases and controls.

The mean value of Elisa protein levels in the case group $(1,246)$ is smaller than the control group $(3,657)$.

\begin{tabular}{|c|c|c|c|c|c|c|c|c|c|c|}
\hline \multicolumn{11}{|c|}{ Table 2. Independent Samples Test } \\
\hline & & \multicolumn{2}{|c|}{$\begin{array}{l}\text { Levene's Test } \\
\text { for Equality of } \\
\text { Variances }\end{array}$} & \multicolumn{7}{|c|}{ t-test for Equality of Means } \\
\hline & & \multirow{2}{*}{$\mathbf{F}$} & \multirow{2}{*}{ Sig. } & \multirow{2}{*}{$\mathbf{t}$} & \multirow{2}{*}{ df } & \multirow{2}{*}{$\begin{array}{l}\text { Sig. } \\
\text { (2-tailed) }\end{array}$} & \multirow{2}{*}{$\begin{array}{l}\text { Mean } \\
\text { Difference }\end{array}$} & \multirow{2}{*}{$\begin{array}{l}\text { Std. Error } \\
\text { Difference }\end{array}$} & \multicolumn{2}{|c|}{$\begin{array}{l}95 \% \text { Confidence } \\
\text { Interval of the } \\
\text { Difference }\end{array}$} \\
\hline & & & & & & & & & Lower & Upper \\
\hline \multirow{2}{*}{$\begin{array}{l}\text { Content } \\
\text { Sandwich } \\
\text { Elisa }\end{array}$} & $\begin{array}{l}\text { Equal variances } \\
\text { assumed }\end{array}$ & 10,668 &, 002 & 12,144 & 58 &, 000 & 2,41100 &, 19853 & 2,01359 & 2,80841 \\
\hline & $\begin{array}{l}\text { Equal variances not } \\
\text { assumed }\end{array}$ & & & 12,144 & 49,684 &, 000 & 2,41100 &, 19853 & 2,01217 & 2,80983 \\
\hline
\end{tabular}

The result of $t$-test showed the sig. value of 0.000 was less than $0.05(<0.05)$. It shows that $\mathrm{H}_{0}$ rejected and $\mathrm{H}_{\mathrm{a}}$ accepted, meaning that there were significant differences between case and control groups.

\section{ROC (Receiver Operating Characteristic) KURVE}

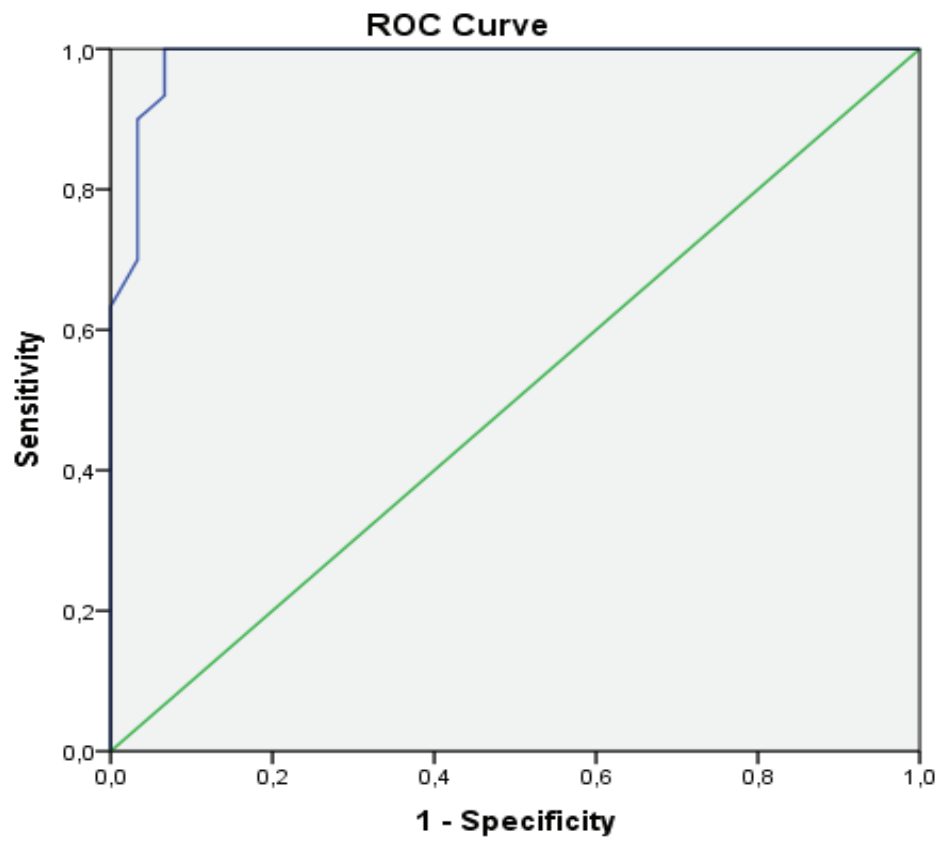

Diagonal segments are produced by ties.

Figure 1. ROC Curves in Case Control Groups

The ROC (Receiver Operating Characteristic) curve shows that the value is far from the $50 \%$ line and close to $100 \%$. 
Table 3. Area Under the Curve

Test Result Variable(s): PROTEIN LEVELS SANDWICH ELISA

\begin{tabular}{|l|l|l|l|l|}
\hline Area & Std. Errora & Asymptotic Sig.b & \multicolumn{2}{|l|}{ Asymptotic 95\% Confidence Interval } \\
\hline & & & Lower Bound & Upper Bound \\
\cline { 3 - 5 } & & &, 962 & 1,000 \\
\hline
\end{tabular}

The test result variable(s): PROTEIN LEVELS SANDWICH ELISA has at least one tie between the positive actual state group and the negative actual state group. Statistics may be biased.

a. Under the nonparametric assumption

b. Null hypothesis: true area $=0.5$

The AUC (Area under the Curve) value is 98.6\% (IK95\%; 96.2\% - 100\%), meaning that if the ELISA Sandwich protein content / content score is used to diagnose the presence or absence of psychotic symptoms due to methamphetamine abuse in 100 clients, then the right conclusion will be obtained at 98.6 clients.

Table 4. Coordinates of the Curve

Test Result Variable(s): PROTEIN LEVELS SANDWICH ELISA

\begin{tabular}{|l|l|l|l|}
\hline No. & Positive if Greater Than or Equal Toa & Sensitivity & $\mathbf{1}$ - Specificity \\
\hline 25 & 1,9600 & 1,000 &, 100 \\
\hline 26 & 2,1650 & 1,000 &, 067 \\
\hline
\end{tabular}

The test result variable(s): PROTEIN LEVELS SANDWICH ELISA has at least one tie between the positive actual state group and the negative actual state group.

The smallest cut-off value is the minimum observed test value minus 1 , and the largest cutoff value is the maximum observed test value plus 1 . All the other cutoff values are the averages of two consecutive ordered observed test values.

\section{Discussion}

As is known that methamphetamine is one type of narcotics that are stimulant, if consumed will affect all parts of the brain, especially in the limbic system, namely the Nucleus Acumbens and Ventral Tegmental Area to activate dopamine (DA), then dopamine is released ${ }^{16}$. from storage. divesicular sites to the cytoplasm so that the amount of DA increases in the brain. Furthermore, DA can carry out automatic oxidation to produce DAQuinones. DA-Kuinon is a very reactive molecule and easily produces semi-quinones that are not stable by the reduction process. Semi-quinones enter the redox cycle together with oxygen molecules to form reactive oxygen species (ROS).

Then, ROS and semi-quinone cause oxidative stress. Therefore, it can be said that this oxidative 
stress plays an important role in the mechanism of MAP, where this is evidenced by the involvement of DA-Kuinon in the mechanism of MAP which induces neurotoxicity and psychotic symptoms in humans ${ }^{14,15}$. DA-quinone is usually detoxified by genes catalyzed by the Quinoneoxidoreductase (NQOs) protein group and also this gene protects brain cell damage from oxidative stress. In humans, genetic evidence indicates that Quinoneoxidoreductase (NQOs) has four gene loci, both of which have been identified as NAD (P) H-quinone oxidoreductase 1 (NQO1) (Ross et al.) and NRH quinoneoxiductase 2 (NQOs) NQO2) ${ }^{9,11}$.

In a research article such as that conducted in Japan by Ohgake, S., et.al with the title "NQO2 gene polymorphism associated with methamphetamine psychosis", in his research found a percentage (11.7\%) D / D of NQO2 genes in patients with prolonged psychosis had double the control (4.8\%). On the other hand, this study shows that the NQO1 polymorphism (Pro187Ser), in which this gene is not associated with MAP abuse. The NQO1 gene is proven to be a risk factor for breast, lung and leukemia ${ }^{3,14,18}$. It has been explained that methamphetamine is a type of narcotic that is stimulant, because it affects the release of excessive dopamine neurotransmitters from Nucleus Accumbens (NA) and Ventral Tegmental Area (VTA) in the Limbic System that causes psychotic disorders. Meanwhile, the NQO2 gene serves to detoxify the effects of excessive dopamine, as well as protect brain organs from the effects of excessive dopamine poisoning which can cause permanent brain damage ${ }^{14}$.

This NQO2 gene is "Helper", so it is normatively assumed that the lack of regulation of the NQO2 gene causes expression of the protein content of the low NQO2 gene, this can cause psychotic disorders in methamphetamine users ${ }^{14,15}$, due to insufficiency. detoxification function and protection of the NQO2 gene. Further studies such as those conducted by Ohgake et al. (regarding the NQO2 gene polymorphism), we then tried to conduct another study, namely how the influence or contribution of protein levels from the NQO2 gene to psychotic disorders in methamphetamine users ${ }^{6}$, 11. Analysis of NQO2 gene protein content through Sandwich Elisa examination for occupants / perpetrators of methamphetamine abuse in the control group (Mental Disorders and Causative Behavior of Amphetamine
Type Non Psychotic Stimulant Type) and case groups (Mental Disorders and Behavior of Addictive Substances of Amphetamine Type of Stimulant with Addictive Substance with Psychotic Type) ) gives different results, where the average value of the protein content in the control group is higher $(3,657)$ than in the case $(1,246)$. Whereas the recommended KURVE ROC (Receiver Operating Characteristic) cut-off is statistically recommended between 1,960 and 2,165 , with a sensitivity value of $100 \%$ and specificity $\geq 90 \%$, it means that a cut-off value osf 1,960 to 2,165 which can be used as a reference for the presence or absence potential psychotic disorders in methamphetamine abuse

\section{Conclusion}

a. The mean value of the NQO2 gene protein level in the Sandwich Elisa examination for the case group ie MAP users $=1,246$, lower than the value of the control group ie non Psychotic MA users $=3,657$. b. The t-test results show the value of sig. (2-tailed) $=0,000$ (smaller than alpha $=0.05(<0.05)$ ), so it can be assumed that there are differences between the samples in the case and control groups. c. Cut-Off CURVE ROC (Receiver Operating Characteristic) recommended statistically in both groups is between 1.960 and 2.165, meaning that if the expression value of protein content> 2.165 then the potential for psychotic suffering is great, on the other hand if $<1.960$, the potential is small for suffering from psychotics $^{2,21}$.

Source of Funding : This study was not sponsored by government or pharmaceutical company fund.

Ethical Clearance : Taken from University Ethical committee

\section{Conflict of Interest: Nil}

\section{References}

1. APA. The Diagnostic and Statistical $M$ a $n$ u a 1 of Mental Disorders (5th ed.). Washington DC: American Psychiatric Association Publishing. 2013.

2. Barr, A. . et al. The need for speed: an update on methamphetamine addiction. J Psychiatry Neurosci, 2006; 31(5), 301-313.

3. Bevins, K. M. G. \& T. D. L. S. M. W. \& M. L. \& S. F. S. H. E. G. \& G. C. \& R. A. Methamphetamine- 
Associated Psychosis. 2012; New York: Neuroimmune Pharmacol.

4. Cruickshank, CC.; Dyer, K. A review of the clinical pharmacology of methamphetamine. Addiction, 2009; 104(7), 1085-1099. Retrieved from http:// onlinelibrary.wiley.com/doi/10.1111/ j.13600443.2009.02564.x/full

5. Daniel F Hermens, Dan I Lubman, Philip B Ward, Sharon L Naismith, I. B. H. Amphetamine psychosis: a model for studying. MJA, 2009; 190.

6. Darke, S.; Kaye, S.; McKetin, R.; Duflou, J. Major physical and psychological harms of methamphetamine use. Drug Alcohol Rev, 2008; 27(3), 253-262.

7. Gabbard, G. Psychodynamic Psychiatry in Clinical Practice (5th ed.). Virginia: American Psychiatric Association Publishing. 2014.

8. Hatta, M. Pelatihan Aplikasi Teknik Biologi Molekular dan Imunologi dalam Penelitian Bidang Kesehatan. Makassar: Laboratorium Biologi Molekular dan Imunologi, 2018; FK UNHAS.

9. Joewana, S. Gangguan Mental dan Perilaku Akibat Penggunaan Zat Psikoaktif: Penyalahgunaan Napza/Narkoba (2nd ed.). 2004; Jakarta: ECG.

10. John. PCP Direct ELISA. Catalog Number MBS580067. 2017

11. Long DJ II, J. A. NRHQuinone oxidoreductase2 (NQO2). ChemBiol Interact, 2000; 129, 99-112.

12. Neil A Campbell, Jane B. Reece, dan L. G. M. Biologi. 2002; Jakarta: Erlangga.

13. NIDA. Genetics of addiction: A research update. Retrieve dfromhttp://www.drugabuse. gov/tib/ genetics/html, 2008.

14. Ohgake, S. K. H. E. S. Functional polymorphism of the NQO2 gene is associated with methamphetamine psychosis. Addiction Biology,2005; 10,145-148. https://doi.org/ 10.1080/ 13556210500123423

15. Okubo T, Harada S, Higuchi S, M. S. Association analysesbetween polymorphisms of the phase II detoxification enzymes(GTSM1, NQO1, NQO2) and alcohol withdrawal symptoms. AlcoholClin Exp Res, 2003; 27(8), 68-71.

16. Oyler JM, Cone EJ, Joseph RE, Moolchan ET, H. M. Duration of detectable methamphetamine and amphetamine excretion in urine after controlled oral administration of methamphetamine to humans. Retrieved August 23, 2018, from http:// www.clinchem.org/cgi

17. Ross D, Kepa JK, Winski SL, Beall HD, Anwar A, S. D. (2000). Nad(p)h:Quinone oxidoreductase 1 (nqo1): Chemoprotection, bioactivation, gene regulation and genetic polymorphisms. Chem Biol Interact, 2002; 129, 77-79.

18. Suryo. Genetika. Jakarta: Departemen P dan K Direktorat Jendral Pendidikan Tinggi. 1996

19. UNODC, L. and S. S. The Challenge of Synthetic Drugs in East and South-East Asia and Oceania : Trends and Patterns of Amphetamine-type Stimulants and New Psychoactive Substances. 2015; Vienna.

20. UU No.35, Tentang Narkotika. Indonesia. 2009

21. Anwar Mallongi, Stang, Syamsuar, Hasnawati Amqam, Aminuddin Syam, Syahrul Basri, Muh. Saleh. 2019., Target Cancer Risks Due To The Exposure From Silica Among The Communities Living Surround Cement Tonasa Industry Pangkep, Indonesia. Interciencia Journal. 2019 44(11)

22. Lequin, RM "Enzyme Immunoassay (EIA)/ Enzyme-Linked Immunosorbent Assay (ELISA)". Clinical Chemistry. 2005; 51 (12): 2415-2418.

23. Koes Irianto. Biologi Molekuler, Penerbit ALFABETA, Bandung, 2017; 546-547.

24. Hatta, M, Eko E. Surachmanto, Andi Asadul Islam, Syarifuddin Wahid. Expression of mRNA IL$17 \mathrm{~F}$ and sIL-17F in atopic asthma patients. BMC Research Notes. 2017; 10:202. DOI: 10.1186/ s13104-017-2517-9. Published: 12 June (2017)

25. Martínez-Cengotitabengoa M, Mac-Dowell KS, Leza JC, Micó JA, Fernandez M, Echevarría E, Sanjuan J, Elorza J, González-Pinto A: Cognitive impairment is related to oxidative stress and chemokine levels in first psychotic episodes. Schizophr Res 2012; 137:66-72 